\title{
Lilac Registration 1990
}

\author{
Freek Vrugtman ${ }^{1}$ \\ Royal Botanical Gardens, Box 399, Hamilton, Ontario L8N 3H8, Canada
}

\begin{abstract}
All correspondence concerned with additional information or plant or propagation material of newly registered lilac cultivars should be directed to the registrants listed below, not to Royal Bottanical Gardens. Previous registration lists of Syringa appeared in AABGA Bul. 13(4):105-110; 14(3):95; 15(3):71-72; 16(4):131-132; 17(3):67-69; 18(3):87; HortSciertce 23(3):458; 24(3):435-436 and 25(6)618.

Syringa reticulata (Blume) Hara 'China Gold'. Fiala. Registered 21 Feb. 1990. Registrar the late Fr. J.F. Fiala of Falconskeape Gardens, Medina, Ohio. Introducer: Ameri-Hort Research, Inc., P.O. Box 1529, Medina, Ohio 44258, USA. Selected by Fiala from seedlings, raised from colchicine-treated seed in 1955; seed produced by open-pollinated $S$. reticulata at Falconskeape Gardens. Original plant first flowered in 1986. Tree similar to $S$. reticulata var. reticulata, but of more upright and narrow habit; early shoots reddish; young leaves light golden, turning pale yellow-green in summer; flower buds and open florets more cream than pure white. Original tree, at 25 years, 7.5 m (25 ft) tall in 1989. Known to be hardy in Arnold Arboretum Hardiness Zone 3. Adaptable to all good soils.
\end{abstract}

${ }^{1}$ Registrar for Syringa. Contribution No. 76, Royal Botanical Gardens, Hamilton, Ontario, Canada.
The following five lilac cultivars have been originated, described, and registered by Adolf Vaigla, Voru 5, 202611 Rapina, Estonia, USSR. The cultivars were selected and named about 20 years ago, but have not yet been introduced into the trade. The cultivar names were registered on 21 Dec. 1990.

Syringa xhyacinthiflora Rehder 'Arvid Vilms'. Vaigla. Selected in 1970 from seedlings grown from seed collected in Canada from open-pollinated S. ×hyacinthiflora 'Clarkes Giant'. Shrubs to $3 \mathrm{~m}$ tall, practically free of sucker growth. Foliage dark-green disease-resistant. Flowers in very large thyrses, fragrant. Florets single, lilac, 3 to $3.5 \mathrm{~cm}$ in diameter, corollas large and with recurved lobes. Plants known to be hardy to $-34 \mathrm{C}$.

Syringa $\times$ hyacinthiflora Rehder 'Vaiga'. Vaigla. Selected in 1970 from seedlings grown from seed collected in Cartada from openpollinated $S$. ×hyacinthiflora 'Esther Staley'. Shrubs to $2.5 \mathrm{~m}$ tall, suckering moderately. Foliage good green, disease-resistant. Flowers appear in mid-season in very large, upright thyrses, fragrant. Florets single, pink to grayish white, 2.8 to $3 \mathrm{~cm}$ in diameter. Plants known to be hardy to $-35 \mathrm{C}$.

Syringa vulgaris L. 'Aino'. Vaigla. Selected in 1969 from seedlings of unknown parentage. Shrubs 2.5 to $3 \mathrm{~m}$ tall, suckering moder- 
ately. Foliage dark-green, disease-resistant. Flowers in $20-$ to $25-\mathrm{cm}$ long upright thymes. fragrant. Florets single, violet-blue, 2 to $2.4 \mathrm{~cm}$ in diameter. Plants thrive in rich loamy soils and are known to be hardy to $-33 \mathrm{C}$.

Syringa vulgaris L. 'Elsa Maasik'. Vaigla. Selected in 1969 from seedlings grown from seed collected from open-pollinated $S$. vulgaris 'Andenken an Ludwig Spath' (='Ludwig Spaeth' in North America). Shrubs of moderate height to $2.5 \mathrm{~m}$, suckering moderately. Foliage dark-green, disease-resistant, Flowers in thyrses to $15 \mathrm{~cm}$ long, fragrant. Florets single, deep-purple, darker than 'Andenken an Ludwig Spath'. 1.8 to $2.2 \mathrm{~cm}$ in diameter. Plants thrive in rich loamy soils and are known to be hardy to $-34 \mathrm{C}$.

Syringa vulgaris L. 'Tilna'. Vaigla. Selected in 1969 from seedlings of unknown parentage. Shrubs to $3.2 \mathrm{~m}$ tall. suckering moderately. Foliage dark-green, disease-resistant Flowers appearing in mid- season; thryrses erect, to $35 \mathrm{~cm}$ long and $12 \mathrm{~cm}$ wide, up to three spikes per thyrse; fragrant. Florets single, pink, to $2.2 \mathrm{~cm}$ in diameter. Known to be hardy to $-34 \mathrm{C}$.

\section{Corrigendum}

Syringa vulgaris L. 'Olive May Cummings'. Berdeen 1979 (syn. 'Elizabeth Files'). The name 'Elizabeth Files' was registered in 1970, but never validly published because it was listed without description in Arnoldia 31(3):122, May 1971. The name 'Olive May Cummings' was registered in 1978 and validly published in AABGA Bul. 13(4):110. Oct. 1979. It appears that both names were applied to one single clone and that few plants were distributed under the name 'Elizabeth Files'. (Personal communication from W.W. Oakes and F. Vrugtman.) 